\title{
Therapeutic Group of The Elderly: Knowledge About Diabetes Mellitus and Arterial Hypertension
}

\section{Grupo Terapêutico de Idosos: Conhecimento Sobre Diabetes Mellitus e Hipertensão Arterial}

\author{
Thalita Araújo dos Santos Santana*a; Murilo da Silva Alves; ${ }^{\mathrm{b}}$ Thais Silva Pereira Campos ; \\ Mônica Pinchemel Nascimento ${ }^{\mathrm{d}}$ \\ ${ }^{a}$ City Hall of Itabuna. BA, Brazil. \\ bUniversidade Estadual de Santa Cruz. BA, Brazil. \\ 'Universidade Estadual do Sudeste da Bahia, Post-Graduate Studies Program in Nursing and Health. BA, Brazil. \\ dUniversidade Estadual da Bahia. BA, Brazil. \\ *E-mail: enfermeira.thalitaaraujo@gmail.com
}

\begin{abstract}
Control and the care are continuous challenges in the treatment of chronic diseases, and it is necessary to know the users' realities in order to seek intervention alternatives. The study aimed to identify the participants' knowledge in a therapeutic group of the elderly regarding diabetes mellitus and systemic arterial hypertension. Descriptive and exploratory study with a qualitative approach, conducted with 12 elderly in the therapeutic group. Semi-structured interviews were used as data collection technique. Data were transcribed and analyzed using the content analysis technique. In the results the category about the participants' knowledge on the diseases emerged, namely: etiological factors; main signs, symptoms and complications; drug therapy; use of herbal medicines; food control; lifestyle and regular follow-up at the health unit. It was concluded that the participants have knowledge about the diseases; however, they cultivate habits that can trigger complications. Knowledge from experience should not be neglected, but should be directed towards achieving the goal of the therapeutic group, helping to improve the understanding of the elderly about their disease (s) and stimulating self-care.
\end{abstract}

Keywords: Therapeutics. Health Education. Chronic Disease. Self-Care.

\section{Resumo}

O controle e o cuidado são desafios contínuos na terapêutica das doenças crônicas, sendo necessário conhecer as realidades dos usuários para buscar alternativas de intervenção. O estudo objetivou identificar o conhecimento dos participantes de um grupo terapêtico de idosos em relação ao diabetes mellitus e hipertensão arterial sistêmica. Estudo descritivo e exploratório, com abordagem qualitativa dos dados. A pesquisa foi realizada no munícipio de Itabuna na Bahia, na Unidade de Saúde da Família Simão Fitterman, no ano de 2014. Participaram do estudo 12 idosos do Sistema de Cadastramento e Acompanhamento de Hipertensos e Diabéticos (HIPERDIA), que participaram das reuniões do grupo terapêutico de idosos. A técnica utilizada para coleta de dados foi a entrevista com roteiro semiestruturado, realizadas nas reuniões do grupo terapêutico da unidade referida. O instrumento de coleta foi composto por dados sócio demográficos, conceitos e fatores desencadeantes das doenças estudadas, tratamento não farmacológico, complicações, prevenção e noções de autocuidado. Concluiu-se que os participantes possuem conhecimento sobre as doenças, entretanto cultivam hábitos que podem desencadear complicações. O conhecimento advindo da experiência, não deve ser negligenciado, mas direcionado ao alcance do objetivo do grupo terapêutico, contribuindo na melhoria do entendimento dos idosos sobre sua (s) doença (s), e estimulando o autocuidado.

Palavras-chave: Terapêutica. Educação em Saúde. Doença Crônica. Autocuidado.

\section{Introduction}

Aging consists of a natural phase of human development, however the social constructions in force perceive the elderly as predisposed to losses, limitations, disabilities, and restrict the "aging" to a passive process that exposes the subject to vulnerability and to the weakening before diseases ${ }^{1}$.

The accelerated process of population aging is a global phenomenon and represents a relevant challenge for public health today. This process, reflecting the best social conditions, the decrease in infant mortality and scientific and technological advances, has resulted in changes in the epidemiological and demographic profile. In this context, non -transmissible chronic diseases, which represent the main cause of death and disability in the world, stand out ${ }^{1-3}$.

In Brazil, the most important impact of chronic non- communicable diseases (NCDs) are systemic arterial hypertension (SAH) and Diabetes mellitus (DM). Due to their high prevalence and association with the appearance of cardiovascular diseases, there are relevant causes of morbidity and mortality in the country, in addition to representing more than half of the primary diagnosis in people with renal failure ${ }^{3,4}$.

With the knowledge of these data and aware of the coexistence of biological and sociocultural determinants, the therapeutic group aimed at the elderly, appears as a resource offered in the context of the family health strategy, aiming at the control of these diseases, favoring, in the best possible way, through its workshops, the reception and qualified listening, guaranteeing the opportunity for participating subjects to become aware of self-care, reaffirming their autonomy, 
the importance of adherence to treatment, increasing the capacity to deal with clinical conditions and their impact on their quality of life ${ }^{5,6}$. It is also proposed to act as a support network, aiming at positively impacting the health conditions of its participants.

Nursing covers issues that involve transcultural care, and is focused on promoting humanized care for people, with citizen interaction, solidarity and coherence, respecting cultural values and lifestyle ${ }^{7,8}$, thus it is possible for the elderly to incorporate and remodel the norms, beliefs, attitudes, expectations and behaviors in the health care offered.

Thus, prior raising the understanding of a group will help to understand the participants' actual needs by allowing actions to be directed and to introduce information that will lead to the change of habits through health education, representing a fundamental strategy for effective treatment aimed at self-care and treatment adherence.

The study aimed to identify the participants' knowledge in a therapeutic group of the elderly regarding diabetes mellitus and systemic arterial hypertension in a city in Bahia state.

\section{Material and Methods}

Descriptive and exploratory study, with data qualitative approach. The research was performed in the city of Itabuna in Bahia, at the Health Unit of Simão Fitterman family, in the year of 2014. 12 elderly attended the study of File and Followup of Systemic Arterial Hypertension and Diabetes Patients (HIPERDIA), who attended the therapeutic group meetings of the elderly.

The technique used for the data collection was interview with semi structured script, performed in meeting of the therapeutic group of the aforementioned unit. The collection instrument was made up of socio-demographic data, concepts and triggering factors of the studied diseases, nonpharmacological treatment, complications, prevention and self-care notions.

The information obtained in the interviews was recorded in audio with the participants' authorization and subsequently transcribed in full and analyzed by the method of content analysis, defined as a group of empirical categories that populate the semantic field defining the concept, causes, associations and significance of the studied phenomenon. The analysis of the meaning nuclei occurred from the careful reading of the speeches with subsequent interpretation of these associating them with the contexts in which they were produced ${ }^{9}$.

Approved by the Research Ethics Committee of the State University of Santa Cruz, this study addressed the ethical aspects of Resolution 196/96 of the National Health Council Protocol 307.145/CAAE: 3408713.5.0000.5526.

The research was conducted in accordance with the required ethical standards, in which the elderly who agreed to participate in the research signed the Written Informed
Consent Form and were named as informants and listed in Arabic numerals from 1 to 12 (example: Informant 5).

\section{Results and Discussion}

The 12 elderly participants/research informants are aged between 64 and 83 years, of which $75.0 \%$ are female; $66.7 \%$ are brown-skinned, $75.0 \%$ are retired; $75.0 \%$ have reported family income less than or equal to a minimum wage; $83.4 \%$ are hypertensive and $16.6 \%$ have concomitant systemic arterial hypertension and diabetes mellitus, 33.3\% have a disease time of 10 years or more. As far as life habits are concerned, $33.3 \%$ are smokers, $16.7 \%$ are heavy drinkers and $91.7 \%$ are sedentary.

The content analysis of the interviews emerged the category: what I know about what I have: diabetes and hypertension.

This category includes knowledge of the etiology of the diseases investigated, the related symptoms, the complications resulting from them, recommended feeding, drug therapy and non-drug therapy, and the contribution of physical activity.

Of the informants, most reported knowing at least one of the diseases etiologic factors, being mentioned predominantly stress, from emotional reactions. "A lot of fright that I had... a lot of anger" (Informant 8), and "Nervousness. Many problems at the time, much concern, many difficult things I went through" (Informant 6).

Smoking and heavy drinking were also mentioned, which were related to illness.

When asked about the symptoms, the informants showed to know the main diseases related to the diseases such as headaches, dizziness, visual problems and weakness. Less frequently, other symptoms such as lower limbs pain, hand and foot dormancy, headache, and tiredness have been reported. Some also reported feeling dormancy directly related to diabetes mellitus.

Few reported the complications of $\mathrm{SAH}$, showing in some speeches the stroke and acute myocardial infarction (AMI). "Stroke. There are a lot of things, but I don't remember". (Informant 3), and "Strike, infarction" (Informant 6).

Most informants demonstrate to recognize the recommendations regarding feeding and relate it to DM and SAH control, and commented on adequate feeding: "do not eat fat, alcohol, salt... avoid sugar". (Informant 4). "fruit, salad, low fat... less salt, decrease fat in food". (Informant 3).

When asked about what they do to control the disease, they reported combining traditional drug therapy with the use of phytotherapy and food control.

Regarding drug therapy, some informants reported knowing and using the prescribed drugs correctly, and diuretics, especially hydrochlorothiazide, were reported as continuous use medications; followed by the use of angiotensin-converting enzyme inhibitors such as captopril and enalapril and $\beta$-blockers, such as propranolol and 
metoprolol.

In addition to the medications, they reported the habit of consuming, concomitantly, boldo teas, cider grass, nuts skin and lavender to alleviate symptoms and/or assist in the treatment itself, especially of SAH, without considering that a tea can nullify or potentiate the drug effects.

Regarding the practice of physical exercises, even though they have knowledge of the main benefits, most reported not practicing any kind of physical activity, even having received guidance on its benefits for the DM and SAH treatment.

The elderly in the study reported regular follow-up of the conditions presented in the health unit and reported having received guidelines regarding the care they need to have concerning the diagnoses.

In addition to demonstrating knowledge about the diseases investigated, the informants reported that the therapeutic group is a strategy that can enable the acquisition of new knowledge and improvement concerning self-care. "I find it very good [therapeutic group] to guide me so I can take better care of myself". (Informant 4). "I hope [...] so that they give me more guidance." (Informant 12)

In the present study, questions about the knowledge of the participants/informants of the therapeutic group regarding the diseases they have were evaluated, and it is possible to infer that there are elderly people who know partially the possible causes of their diseases, which are predominantly associated with emotional factors, such as anger or stress.

Increased production of hormones involved in stress response increases the risk of developing visceral obesity, metabolic syndrome and glucose intolerance ${ }^{10}$. Stress control combined with the maintenance of adequate weight, regular practice of physical activity, moderate alcohol and caffeine consumption, as well as smoking cessation, improve factors that trigger chronic non-communicable diseases such as diabetes and hypertension ${ }^{11}$. Although some recognize these life habits as triggering factors, they are not considered as the main factors for the development of chronic diseases.

The elderly end up considering the signs and symptoms that characterize the diseases and not the factors that triggered the process, which becomes understandable when analyzing the perception about the current health-disease process and not the determinants or conditions of the health state.

It is known that not controlling the above factors may interfere in the success of treatment and compromise the quality of life idealized by the actions of the family health strategy ${ }^{10,12}$. SAH and DM are the most frequent diseases in industrialized countries, and the interrelationship between them is the object of study worldwide. In addition, it is estimated that 35.0 to $75.0 \%$ of the complications occurring in DM can be attributed to hypertension ${ }^{11}$.

Previous knowledge that the participants have about the disease itself is indispensable for the adoption of actions, which aims to facilitate adherence to treatment, which will also contribute to the establishment of therapeutic monitoring and the users' education. In this study, most participants expressed knowledge of the main symptoms of SAH and DM and the possible complications resulting from these diseases. It is important to emphasize that self-knowledge of the above diseases favors the success of the treatment and improvement of the quality of life of the affected people.

In a study carried out in the state of Minas Gerais that evaluated the users' knowledge in the context of the Family Health Strategy, it was observed that $50.0 \%$ of the elderly interviewed knew some of the DM symptoms ${ }^{13}$. Among the symptoms reported by the elderly in the above-mentioned study, hypoglycemia, polydipsia, polyuria and polyphagia stand out.

The inadequacy of glycemic and pressure control are the main risk factors for the development of complications of DM and SAH, and these predispose to the appearance of disability and death. For this reason, preventive systematic examination and rapid access to treatment are considered relevant for the prevention of complications.

Results similar to those of the present study were found in relation to the complications of the diseases studied, and renal impairment was added as one of the most relevant complications $^{14}$. In a research performed by Cotta et al. ${ }^{13}$ that addresses the complications resulting from DM, visual alterations and diabetic foot, cardiovascular problems (mainly stroke and myocardial infarction), hypertension, dyslipidemia and nephropathy were predominantly evidenced. The same study corroborated with the present study, in which it also demonstrated that $33.3 \%$ of the interviewees did not know the complications resulting from DM.

As for living habits, the participants demonstrated understanding the importance of maintaining healthy eating and avoiding alcohol or cigarette consumption, however, some participants stated that they are smokers and heavy drinkers, which can be considered as a point of difficulty for the chronic diseases control. Nicotine present in cigarettes contributes to the blood pressure elevation and predisposes to greater cholesterol deposition in blood vessels ${ }^{12}$. Despite the lack of studies that prove the relationship between smoking and diabetes, some prospective studies have shown an increase in the incidence of type $2 \mathrm{DM}$ in smokers ${ }^{1,11}$. For SAH and DM, they observed that the increased risk for these diseases was directly associated with alcohol consumption. The control of risk factors is pointed out in the literature as determinant to avoid or delay damage to target organs in both pathologies $^{1,10,11}$.

The recommended diet emphasizes the consumption of natural foods with low lipid content and encouragement of the consumption of vegetables, fruits, cereals, vegetables, fibers, vitamins, minerals and antioxidant substances. In addition, food intake must be disciplined, fractioned in several meals and combined with regular practice of physical exercises. As supporting elements to dietary treatment, fundamental measures are needed, such as reducing alcohol consumption, 
smoking cessation, body weight reduction and physical activity practice ${ }^{11,15}$.

Most of the elderly in this study reported not performing any kind of physical activity. Physical inactivity is associated with the development of chronic non-communicable diseases (NCDs), and sedentary lifestyle is an important risk factor for the development of diseases such as diabetes and cardiovascular diseases. In addition to combating sedentary lifestyle and improving the elderly functional capacity, regular exercise contributes to improving body composition, glycemic and lipid profile, decreased metabolic rate and joint pain, reduced vascular resistance, combating depression and stimulating self-confidence, which allows the physical activity to be given the title of a protective factor of functional capacity, especially in the elderly ${ }^{16,17}$.

The control therapeutics of SAH and DM is significantly associated with the healthy lifestyle, which involves, among other things, regulated use of salt and fat, carbohydrates, sugar, alcohol and nicotine abstention, regular practice of physical activity, stress control and obesity reduction ${ }^{17,18}$. The adoption of the above-mentioned care combined with drug therapy contributes to the adequate control of the chronic diseases studied, signaling the importance of investing in the dissemination of these care and in the exchange of knowledge between professional and user.

Regarding the treatments of the diseases presented, the participants of this study prioritized the use of medications prescribed by the physician. As for the knowledge of the medications, a significant portion reported knowing the main drugs and the correct way of use.

The main objective of the treatment of arterial hypertension is to reduce cardiovascular morbidity and mortality. Thus, antihypertensive drugs should not only reduce blood pressure, but should simultaneously reduce associated fatal and nonfatal cardiovascular events and contribute to a decrease in mortality rate ${ }^{12}$. The current treatment of DM aims to reduce insulin resistance and improve the function of the $\beta$-pancreatic cell $^{12}$.

Some participants also reported using complementary therapies in the treatment such as the use of phytotherapy and some teas. Phytotherapy has been widely used as complementary therapy in the treatment of several diseases. Studies have shown that teas have also been cited as complementary measures to treatment ${ }^{18-20}$.

When caring for the person with hypertension and/or diabetes, some goals should be pursued by the nursing team, such as understanding the pathological process, treatment and encouragement of the individual to participate in selfcare programs, as well as certification of the absence of complications, lifestyle changes and use of medications ${ }^{18,21,22}$. In the informants' speeches, it can be demonstrated that within health care there is interference of some knowledge acquired in society which constitute a cultural heritage of a people being inseparable from the individual and must be used for the success of the therapy.

In this sense, a study carried out with participants of an educational diabetes program analyzing knowledge, attitudes, and self-care practices in these individuals emphasized the importance of educational activities in health not only to pass on information, but also to builders of knowledge, highlighting that shared experiences in groups, have more impact on the construction of users' knowledge than lectures and explanations, demonstrating clinical improvement after participation in educational groups ${ }^{23}$.

\section{Conclusion}

The analysis of the elderly' speeches showed the existence of self-knowledge regarding the etiology, symptoms, complications and recommended feeding for the diseases investigated. This prior knowledge derived from the experience has been permeated with significance for the person with chronic disease and should not be neglected; instead, it should be worked and directed toward the desired objective with the actions of the therapeutic group, that is, diabetes and hypertension control and improvement of the quality of life of the participants in the group.

It is known that adherence to the treatment of chronic diseases is complex, since it involves changes in habits permanently, which suggests the need to consider the coresponsibility of the subject regarding his or her treatment, since people of different cultures are able to guide their care in different ways according to their beliefs, values and customs.

Due to that, the importance is noticed on developing care strategies for therapeutic groups of elderly people, with a view to the construction and/or re-fitting of knowledge regarding their own health-disease process as well as the stimulation of the development of self-care actions, narrowing the distance between knowledge and the adoption of control practices.

The study limitations are found in the sample size, as well as in the search for an understanding on the knowledge formation identified in the elderly about chronic diseases, which could help in the working process of the therapeutic groups concerning Diabetes Mellitus and arterial hypertension.

\section{References}

1. Coimbra AMC, Borges APA. Envelhecimento e saúde da pessoa idosa. Rio de Janeiro: EAD/ENSP; 2014.

2. Brasil. Ministério da Saúde. Plano de ações estratégicas para o enfrentamento das doenças crônicas não transmissíveis (DCNT) no Brasil. Brasília: MS; 2011.

3. Alves MS, Araujo, MCF, Nascimento M P, Ribeiro FC, Rebouças PT, Santos TA, Santos NA, et al. Grupo Terapêutico com idosos sobre o autocuidado nas doenças crônicas. J Health Sci 2016;18(1):48-51.

4. Freitas EV, Py L. Tratado de geriatria e gerontologia. Rio de Janeiro: Guanabara Koogan; 2011.

5. Fortuna CM, Matumo S, Pereira MJB, Mishima SM, Kawata LS, Camargo-Borges C. O enfermeiro e as práticas de cuidados coletivos na estratégia saúde da família. Rev 
Latinoam Enferm 2011;19(1).

6. Garcia MAA, Yagi GH, Souza CS, Odoni APC, Frigério RM, Merlin SS. Atenção à saúde em grupos sob a perspectiva dos idosos. Rev Latinoam Enferm 2006;14(2). doi: http://dx.doi. org/10.1590/S0104-11692006000200005.

7. Fortuna CM, Matumoto S, Pereira MJB, Camargo-Borges C, Kawata LS, Mishima SM. Educação permanente na estratégia saúde da família: repensando os grupos educativos. Rev Latinoam Enferm 2013;21(4):

8. Melo MC, Souza AL, Leandro EL, Mauricio EA, Silva ID, Oliveira JMO. A educação em saúde como agente promotor de qualidade de vida para o idoso. Ciênc Saúde Coletiva 2009;14(1). doi: http://dx.doi.org/10.1590/S141381232009000800031 .

9. Bardin L. Análise de conteúdo. Lisboa: Edições 70; 2011.

10. Sociedade Brasileira de Cardiologia. Sociedade Brasileira de Hipertensão. Sociedade Brasileira de Nefrologia. VI Diretrizes Brasileiras de Hipertensão. São Paulo: ANAD; 2015.

11. Oliveira JEP, Vencio S. Diretrizes da Sociedade Brasileira de Diabetes: 2013-2014/Sociedade Brasileira de Diabetes. São Paulo: AC Farmacêutica; 2014.

12. Girotto E, Andrade SM, Cabrera MAS, Matsuo T. Atenção ao tratamento farmacológico e não farmacológico e fatores associados na atenção primária da hipertensão arterial. Cienc Saúde Coletiva 2013;18(6). doi: http://dx.doi.org/10.1590/ S1413-81232013000600027.

13. Cotta RMM, Reis RS, Carvalho AL, Batista KCS, Castro FAF, Alfenas, RAG. Reflexões sobre o conhecimento dos usuários no contexto do Programa de Saúde da Família: a lacuna entre o saber técnico e o popular. Physis 2008;8(4). doi: http://dx.doi.org/10.1590/S0103-73312008000400008.

14. Péres DS, Magna JM, Viana LA. Portador de hipertensão arterial: atitudes, Crenças, percepções, pensamentos e práticas. Rev. Saúde Pública 2003;37(5). doi: http://dx.doi. org/10.1590/S0034-89102003000500014.
15. Orsolin C, Rufatto C, Zambonato RX, Fortes VLF, Pomati DM. Cuidando do ser humano hipertenso e protegendo sua função renal. Rev Bras Enferm 2005;58(3). doi: http://dx.doi. org/10.1590/S0034-71672005000300012.

16. Nogueira IC, Santos ZMSA, Mont'Alverne DGB, Martins $\mathrm{ABT}$, Magalhães CBA. Efeitos do exercício físico no controle da hipertensão arterial em idosos: uma revisão sistemática. Rev Bras Geriatr Gerontol 2012;15(3). doi: http://dx.doi. org/10.1590/S1809-98232012000300019.

17. Santos HLBA, Nascimento FMR, Freitas CMSM, Cunha AEV, Vancea DMM. Motivação do diabético tipo 2 para o tratamento não farmacológico. Rev Bras Ativ Fís Saúde 2012;17(6).

18. Alves MS, Araújo MCF, Castro RR, Rebouças PT, Castro GE, Santana M V F, et al. Satisfação dos usuários do Programa Medicamento em Casa em uma Equipe de Saúde da Família em município baiano. UNOPAR Cient Ciênc Biol Saúde 2015;17(3):154-9.

19. Firmo JOA, Lima-Costa MF, Uchoa E. Projeto Bambuí: maneiras de pensar e agir de idosos hipertensos. Cad. Saúde Pública 2004;20(4). doi: http://dx.doi.org/10.1590/ S0102-311X2004000400018.

20. Cunha PRMS, Castelo Branco DR, Bernardes ACF, Aguiar MIF, Rolim ILTP, Linard AG. Prevalência e causas de não adesão ao tratamento anti-hipertensivo de idosos na atenção básica. Rev Pesq Saúde 2012;13(3):11-6.

21. Lopes MCL, Carreira L, Marcon SS, Souza AC, Waidman MAP. O autocuidado em indivíduos com hipertensão arterial: um estudo bibliográfico. Rev Eletr Enf 2008;10(1).

22. Figueiredo NN, Asakura L. Adesão ao tratamento antihipertensivo: dificuldades relatadas por indivíduos hipertensos. Acta Paul Enferm 2010;23(6). doi: http://dx.doi. org/10.1590/S0103-21002010000600011.

23. Torres, HC Souza ER, Lima MHM, Bodstein RC. Intervenção educativa para o autocuidado de indivíduos com diabetes mellitus. Acta Paul Enferm 2011;24(4). doi: http://dx.doi. org/10.1590/S0103-21002011000400011. 